\title{
CRITICAL REFLECTION AND FEEDBACK FOR MEDICAL STUDENTS: A COMPARATIVE STUDY
}

\author{
Imelda Ritunga*, Gandes Retno Rahayu**, Yoyo Suhoyo** \\ * Magister Pendidikan Kedokteran, Fakultas Kedokteran, Kesehatan Masyarakat dan Keperawatan \\ Universitas Gadjah Mada, Yogyakarta - INDONESIA \\ ** Fakultas Kedokteran, Kesehatan Masyarakat dan Keperawatan Universitas Gadjah Mada, Yogyakarta - INDONESIA
}

\begin{abstract}
Background: The physician who reflects critically will interpret the experience, aware of its limitations, and will become life long learner. When implementing reflection learning in medical education, it is necessary to assess the ability of learners to help improve the ability of reflection. The objective of the research is to know the students 'reflection ability by giving feedback and different of reflection ability between intervention group and control group.
\end{abstract}

Method: Research using pre and post control group design. The subjects of the study were 62 students medical students of Faculty of Medicine UGM year II who had collected narrative reflection to Gamel ( $n=176$ students) and willing to participate, divided into 2 groups with simple random sampling. Intervention of treatment group are giving feedback based on the result of narrative reflection from Gamel followed by narrative reflection assignment. The subjects' narrative reflection was assessed using the REFLECT rubric, and analyzed by Wilcoxon and MannWhitney tests.

Results: The results showed that students' pre and post test reflection ability is in the reflection stage. Giving feedback once does not increase the ability from reflection stage to the critical reflection stage. This result may be due to several things: critical reflection does not occur without significant / dramatic experience that shifts perspective resulting in transformative learning, feedback is given regularly, lack of trustworhty to instructors who are not university lecturers. Another result of a decrease in the ability of reflection in general after 6 months indicates the need to do reflection activity / assignment in each semester to maintain and improve the ability of reflection. Conclusion: Increased reflection ability from reflection stage to critical reflection stage does not occur with single feedback. If reflection is not done regularly, it can cause a decrease in reflection ability.

Keywords: reflection ability, narrative reflection, critical reflection, feedback

\begin{abstract}
ABSTRAK
Latar belakang: Dokter yang berefleksi kritis akan memaknai pengalaman, menyadari keterbatasannya, sehingga akan belajar sepanjang hayat. Saat mengimplementasikan pembelajaran refleksi di pendidikan kedokteran, dibutuhkan penilaian untuk mengetahui kemampuan peserta didik agar dapat membantu meningkatkan kemampuan refleksi. Tujuan penelitian adalah untuk mengetahui kemampuan refleksi mahasiswa dengan pemberian umpan balik dan kemampuan refleksi mahasiswa kelompok perlakuan dan kelompok kontrol.

Metode: Penelitian menggunakan pre and post control group design. Subyek penelitian adalah 62 mahasiswa kedokteran FK UGM tahun ke-2 yang telah mengumpulkan refleksi naratif ke Gamel(n=176 mahasiswa) dan bersedia berpartisipasi, dibagi menjadi 2 kelompok dengan simple random sampling. Intervensi kelompok perlakuan berupa pemberian umpan balik berdasarkan hasil refleksi naratif dari Gamel diikuti dengan penugasan refleksi naratif. Refleksi naratif subyek penelitian dinilai dengan menggunakan rubrik REFLECT, dan dianalisa dengan uji Wilcoxon dan uji Mann-Whitney.
\end{abstract}

contact: imelda.ritunga@ciputra.ac.id 
Hasil: Hasil penelitian menunjukkan kemampuan refleksi mahasiswa pre dan post test berada pada tahap refleksi. Pemberian umpan balik satu kali tidak meningkatkan kemampuan refleksi ke tahap refleksi kritis. Hasil ini dapat disebabkan oleh beberapa hal: refleksi kritis tidak terjadi tanpa pengalaman penting/ dramatik yang dapat menggeser perspektif sehingga terjadi pembelajaran transformatif, pemberian umpan balik perlu diberikan secara reguler, kurangnya trustworhty terhadap instruktur yang bukan dosen mahasiswa. Hasil lainnya terjadi penurunan kemampuan refleksi secara umum setelah melewati 6 bulan menandakan perlu dilakukan aktivitas/penugasan refleksi di tiap semester untuk mempertahankan dan meningkatkan kemampuan refleksi.

Kesimpulan: Peningkatan kemampuan refleksi dari tahap refleksi ke tahap refleksi kritis tidak terjadi dengan sekali pemberian umpan balik. Jika refleksi tidak dilakukan secara reguler, dapat menyebabkan penurunan kemampuan refleksi.

Kata kunci: kemampuan refleksi, refleksi naratif, refleksi kritis, umpan balik

\section{PENDAHULUAN}

Salah satu pembelajaran yang penting bagi mahasiswa kedokteran dalam mempersiapkan diri menjadi dokter adalah pembelajaran refleksi. Melalui pembelajaran refleksi, setiap mahasiwa dilatih melihat pengalamannya dan memaknainya dalam melakukan perbaikan. Dengan refleksiseorang dokter akan menyadari keterbatasannya dan akan belajar sepanjang hayat. ${ }^{1}$ Pembelajaran sepanjang hayat merupakan proses yang terus menerus, yang menyatu dalam praktik profesional sehari-hari. Oleh karena itu, kemampuan refleksi merupakan parameter hasil yang penting bagi profesional kesehatan. ${ }^{2}$ Tanpa refleksi kritis, dokter berpotensi melakukan diagnosa dan terapi yang kurang akurat serta cenderung mengulang kesalahannya sehingga akan merugikan pasien maupun dokter. Pada pasian akan menjadi beban waktu, tenaga, dan biaya sedangkan pada dokter akan terbentur dengan etika dan hukum kedokteran.

Refleksi dalam konteks pembelajaran merupakan suatu aktivitas intelektual dan afektif individu dalam menggali pengalamannya untuk menuju pada pemahaman dan apresiasi baru. Refleksi menurut Mezirow dibedakan menjadi³: 1) tindakan kebiasaan, 2) tindakan bijaksana, 3) intropeksi, 4) refleksi, dan 5) refleksi mendalam/refleksi kritis. Refleksi melibatkan kritik dari asumsi tentang muatan atau proses untuk pemecahan masalah. Refleksi kritis adalah refleksi mendalam yang dapat mengubah kerangka makna menuju transformasi perspektif. Refleksi kritis menyadarkan dan menganalisa pengetahuan dan pengalaman kita untuk mencapai makna dan pengertian mendalam menuju transformasi perspektif. ${ }^{3-5}$

Standar Kompetensi Dokter Indonesia (SKDI) menyebutkan 7 area kompetensi yang harus dimiliki seorang dokter, salah satunya adalah mawas diri dan pengembangan diri, merupakan pondasi kompetensi dokter. Komponen mawas diri dan pengembangan diri terdiri atas: 1) menerapkan mawas diri, 2) mempraktekkan belajar sepanjang hayat, dan 3) mengembangkan pengetahuan. Dalam menerapkan mawas diri, praktek belajar sepanjang hayat, dan pengembangan pengetahuan, diperlukan refleksi terutama refleksi kritis. ${ }^{6}$

Implementasi refleksi dalam kurikulum bertujuan agar mahasiswa mampu melakukan refleksi kritis sehingga penilaian refleksi menjadi tolak ukur kemampuan mahasiswa. Walaupun belum ada penilaian terhadap kemampuan refleksi mahasiswa, observasi yang dilakukan pada beberapa mahasiswa kedokteran akhir tahun pertama menunjukkan kemampuan refleksi yang belum optimal. Untuk meningkatkannya, dapat dibantu dengan pemberian umpan balik.

Umpan balik adalah informasi yang diberikan kepada pembelajar yang bertujuan memodifikasi pemikiran atau perilaku mereka untuk meningkatkan pembelajaran? ${ }^{7}$. Umpan balik yang baik dapat meningkatkan proses pembelajaran dan 
hasil pembelajaran secara signifikan, jika diberikan dengan benar. Hasil penelitian menyatakan umpan balik terstruktur menstimuli peningkatan refleksi. ${ }^{8}$ Dalam hal pembelajaran refleksi, Wald dkk menyatakan bahwa pemberian umpan balik tertulis oleh instruktur pada refleksi naratif dapat meningkatkan proses refleksi yang lebih dalam. ${ }^{1}$

Tujuan penelitian ini adalah untuk melihat kemampuan refleksi mahasiswa kedokteran dengan pemberian umpan balik.

\section{METODE}

Jenis penelitian berupa pre and post test control group design. ${ }^{9}$ Subyek penelitian adalah mahasiswa kedokteran FK UGM angkatan 2015 yang telah mengumpulkan refleksi naratif ke Gamel( $n=176$ mahasiswa) dan bersedia berpartisipasi sejumlah 62 mahasiswa. Pada penelitian ini, subyek penelitian dibagi kedalam kelompok perlakuan dan kelompok kontrol melalui simple random sampling.

Variabel penelitian berupa kemampuan refleksi mahasiswa yang dinilai dengan menggunakan rubrik REFLECT sebagai variabel terikat dan pemberian umpan balik sebagai variabel bebas. Kemampuan refleksi mahasiswa adalah peningkatan kemampuan refleksi melalui penilaian rubrik REFLECT sebelum dan setelah diberikan umpan balik. Materi refleksi naratif berupa pengalaman belajar mahasiswa sebelumnya. Intervensi umpan balik berupa pemberian 1 kali umpan balik kepada mahasiswa berdasarkan hasil penilaian refleksi dengan metode Pendleton.

Instrumen penelitian yang digunakan berupa rubrik REFLECT (Reflection Evaluation for Learners' Enhanced Competencies Tool) oleh Wald dkk. ${ }^{1}$ Instrumen ini memiliki 5 kriteria yaitu: 1) spektrum tulisan, 2) keberadaan, 3) gambaran konflik atau dilema, 4) kehadiran emosi, 5) analisa dan pemaknaan. Penilaian dibuat dalam 5 skala Likert, yaitu: 0 adalah kebiasaan/tidak reflektif, 1 adalah tindakan yang dipikirkan/introspeksi, 2 adalah refleksi, 3 adalah refleksi kritis, dan 4 adalah belajar transformatif/konfirmatif. Skala 4 dapat terjadi jika seluruh kriteria memenuhi skala 3. Rubrik ini diterjemahkan ke dalam Bahasa Indonesia dan telah divalidasi oleh 2 ahli pendidikan kedokteran.
Sebelum melakukan penelitian, terlebih dulu dilakukan interrater reliability dengan hasil 0,789 $(>0,5)$ yang berarti reliabilitas antar rater cukup memadai sehingga rubrik REFLECT dikatakan cukup reliabel. ${ }^{10}$ Penelitian dilakukan dengan :tahapan-tahapan sebagai berikut

\section{Tahap Persiapan:}

1. Permohonan ijin ke komite etik FK UGM, ke Fakultas Kedokteran UGM, serta melakukan informed concent kepada mahasiswa angkatan 2015 yang telah mengumpulkan tugas refleksi.

2. Tahap pelatihan dan penyamaan persepsi instruktur menggunakan instruksional desain oleh Gagne dkk diikuti interater reliability dengan ICC. ${ }^{11}$

\section{Tahap pelaksanaan:}

1. Instruktur menilai refleksi naratif mahasiswa sebagai nilai pre test yang menjadi dasar pemberian umpan balik.

2. Mengundang mahasiswa kelompok perlakuan untuk mendapatkan umpan balik berdasarkan hasil refleksi naratif dari Gamel dengan pengaturan waktu 15 menit bagi tiap mahasiswa untuk mendapat umpan balik dari instruktur yang menilai hasil refleksi mereka. Umpan balik diberikan dengan teknik the pendleton model, yang urutannya: 1) mahasiswa menyatakan apa yang sudah baik pada refleksi naratifnya, 2) instruktur menyetujui bagian yang telah baik dan mengelaborasi hasil refleksi naratif mahasiswa, 3) mahasiswa menyatakan apa yang kurang pada refleksi naratifnya, 4) Instruktur memberi masukan untuk meningkatkan refleksi. Pemberian umpan balik menggunakan model Pendleton dengan masukan untuk meningkatkan performa menuju refleksi kritis (skor 3) pada rubrik REFLECT. Setelah itu, mahasiswa kelompok perlakuan diberi tugas membuat naratif dengan konten yang sama dan dikumpulkan;

3. Mengundang mahasiswa kelompok kontrol untuk membuat refleksi naratif dengan konten yang sama dan dikumpulkan.;

4. Hasil refleksi naratif mahasiswa/post test yang terkumpul di nilai dengan menggunakan rubrik 
REFLECT oleh instruktur tanpa mengetahui identittas mahasiswa. Hasil pre dan post test dikumpulkan, lalu dianalisa dengan menggunakan SPSS.

\section{Tahap Analisa:}

Hasil refleksi naratif pre dan post di analisa dengan menggunakan uji non parametrik karena menggunakan data skala ordinal. Perbandingan hipotesis komparatif kelompok perlakuan dengan kelompok kontrol dianalisa dengan uji Mann-Whitney $U$ test. ${ }^{12,13}$ Perbedaan tingkat refleksi mahasiswa kelompok perlakuan dan kontrol dikatakan bermakna jika nilai $\mathrm{p}<0,05$. Setelah penelitian, mahasiswa kelompok kontrol akan mendapatkan umpan balik sebagai tanggung jawab moral.

Keterbatasan penelitian ini adalah subyek penelitian yang tidak dapat dipisahkan/di kontrol sepenuhnya karena konteks penelitian berada pada pendidikan yang sedang berjalan sehingga subyek dapat saling mempengaruhi. Strategi yang dilakukan untuk mengatasi yaitu dengan pemberian umpan balik segera diikuti dengan tugas refleksi naratif berikutnya (post test). Keterbatasan lainnya adalah subyektivitas instruktur yang akan menilai, untuk meminimalisir dilakukan reliabilitas interrater dengan Interclass Coefficient(ICC).

\section{HASIL DAN PEMBAHASAN}

Subyek penelitian sebanyak 62 orang terdiri dari 29 laki-laki dan 33 perempuan, dibagi dengan simpel random menjadi 31 kelompok perlakuan dan 31 kelompok kontrol. Jumlah mahasiswa perempuan lebih banyak karena perbandingan mahasiswa perempuan lebih banyak pada angkatan tersebut juga yang bersedia berpartisipasi lebih banyak perempuan. Data yang telah dikumpulkan terlebih dahulu dilakukan uji normalitas dengan menggunakan Shapiro-Wilk. Hasil normalitas ke-5 kriteria refleksi pada penelitian ini menunjukkan $p=0,000 \quad(p<0,05)$, yang berarti data tidak terdistribusikan normal, sehingga menggunakan uji Wilcoxon untuk menilai hasil pre dan post test mahasiswa serta menggunakan uji Mann-Whitney untuk melihat perbedaan kelompok perlakuan dan kelompok kontrol. Data deskripsi berupa refleksi naratif mahasiswa secara umum dan tingkat refleksi mahasiswa pada pembelajaran refleksi kritis dinilai dengan 5 kriteria menurut instrumen rubrik REFLECT seperti yang dapat dilihat pada Tabel 1 dan Tabel 2, sementara rubrik REFLECT dapat dilihat pada lampiran.

Tabel 1. Persentase frekuensi kriteria penilaian pre \& post test kelompok perlakuan

\begin{tabular}{lcrrrrrrr}
\multicolumn{1}{c}{ Kategori } & \multicolumn{4}{c}{ Pre test (\%)* } & \multicolumn{5}{c}{ Post test (\%)* } \\
\cline { 2 - 9 } & K & I & R & RK & K & I & R & RK \\
- Spektrum tulisan & 0 & 10 & 61 & 29 & 0 & 23 & 61 & 16 \\
- Keberadaan & 0 & 0 & 35 & 65 & 0 & 7 & 32 & 61 \\
- Gambaran konflik & 0 & 10 & 61 & 29 & 0 & 29 & 58 & 13 \\
- Kehadiran emosi & 0 & 16 & 61 & 3 & 3 & 19 & 65 & 13 \\
- Analisis \& pemaknaan & 0 & 0 & 75 & 19 & 0 & 29 & 61 & 10 \\
\hline
\end{tabular}

$\mathrm{K}=$ Kebiasaan; $\mathrm{I}=$ Intropeksi; $\mathrm{R}=$ Refleksi; $\mathrm{RF}=$ Refleksi kritis, * = pembulatan desimal

Tabel 2. Persentase frekuensi kriteria penilaian pre $\&$ post test kelompok kontrol

\begin{tabular}{lcccccccc}
\multirow{2}{*}{\multicolumn{1}{c}{ Kategori }} & \multicolumn{4}{c}{ Pre test (\%)* } & \multicolumn{4}{c}{ Post test (\%)* } \\
\cline { 2 - 9 } & K & I & R & RK & K & I & R & RK \\
- Spektrum tulisan & 0 & 10 & 61 & 29 & 9 & 10 & 42 & 38 \\
- Keberadaan & 0 & 10 & 45 & 45 & 7 & 6 & 26 & 61 \\
- Gambaran konflik & 0 & 19 & 49 & 32 & 0 & 16 & 52 & 32 \\
- Kehadiran emosi & 0 & 23 & 51 & 26 & 3 & 20 & 58 & 19 \\
- Analisis \& pemaknaan & 0 & 16 & 68 & 16 & 3 & 32 & 42 & 23 \\
\hline
\end{tabular}


Hasil tes Wilcoxon pada kelompok perlakuan maupun pada kelompok kontrol memperlihatkan kemampuan refleksi pada pre test dan post test secara umum berada di tahap refleksi. Baik kelompok perlakuan maupun kelompok kontrol setelah melewati 6 bulan (jarak pre dan post test) secara umum mengalami penurunan kemampuan refleksi. Hasil uji beda antara kelompok perlakuan dan kelompok kontrol di ukur dengan menggunakan uji Mann-Whitney menunjukkan rentang nilai $p=0,213$ hingga $p=0,980$ yang berarti tidak ada perbedaan bermakna $(\mathrm{p}<0,05)$ antara kelompok perlakuan dengan kelompok kontrol seperti yang dapat dilihat pada Tabel 3.

Tabel 3. Uji Mann-Whitney kelompok perlakuan dengan kontrol pre $\mathbb{\&}$ post test.

\begin{tabular}{|c|c|c|c|c|}
\hline \multirow[b]{2}{*}{ Kriteria } & \multirow[b]{2}{*}{ Kelompok } & \multicolumn{2}{|c|}{ REFLECT } & \multirow[b]{2}{*}{ Signifikan } \\
\hline & & $\begin{array}{c}\text { Sebelum } \\
\text { Median(IR) }\end{array}$ & $\begin{array}{c}\text { Sesudah } \\
\text { Median(IR) }\end{array}$ & \\
\hline spektrum tulisan & $\begin{array}{l}\text { - perlakuan } \\
\text { - kontrol }\end{array}$ & $\begin{array}{l}2(2-3) \\
2(2-3)\end{array}$ & $\begin{array}{l}2(1,5-2) \\
2(2-3)\end{array}$ & 0,453 \\
\hline keberadaan & $\begin{array}{l}\text { - perlakuan } \\
\text { - kontrol }\end{array}$ & $\begin{array}{l}3(2-3) \\
2(2-3)\end{array}$ & $\begin{array}{l}3(2-3) \\
3(2-3)\end{array}$ & 0,401 \\
\hline gambaran konflik & $\begin{array}{l}\text { - perlakuan } \\
\text { - kontrol }\end{array}$ & $\begin{array}{l}2(2-3) \\
2(2-3)\end{array}$ & $\begin{array}{l}2(1-2) \\
2(2-3)\end{array}$ & 0,213 \\
\hline kehadiran emosi & $\begin{array}{l}\text { - perlakuan } \\
\text { - kontrol }\end{array}$ & $\begin{array}{l}2(2-2) \\
2(1,5-2,5)\end{array}$ & $\begin{array}{l}2(1,5-2) \\
2(1,5-2)\end{array}$ & 0,981 \\
\hline analisis \& pemaknaan & $\begin{array}{l}\text { - perlakuan } \\
\text { - kontrol }\end{array}$ & $\begin{array}{l}2(2-2) \\
2(2-2)\end{array}$ & $\begin{array}{l}2(1-2) \\
2(1-2)\end{array}$ & 0,441 \\
\hline
\end{tabular}

Hasil penelitian menunjukkan mayoritas nilai pre dan post tes refleksi naratif berada di level refleksi. Pemberian umpan balik satu kali terhadap kelompok perlakuan tidak meningkatkan kemampuan dari tahap refleksi ke tahap refleksi kritis. Tidak ada perbedan bermakna antar mahasiswa kelompok perlakuan dan kelompok kontrol. Hasil penelitian juga didapatkan penurunan level refleksi mahasiswa secara umum baik pada kelompok perlakuan maupun pada kelompok kontrol pada post test setelah melewati 6 bulan. Beberapa hal dapat menyebabkan hasil tersebut.

Pertama, refleksi kritis tidak sering terjadi dalam kehidupan sehari-hari. Kemampuan refleksi mahasiswa di tahap refleksi tidak meningkat menjadi refleksi kritis bisa disebabkan karena tidak ada pengalaman penting/dramatic yang menggeser perspektif mahasiswa. Menurut Sandars, pengalaman yang dramatik menghasilkan pergeseran besar terhadap perspektif, sehingga terjadi pembelajaran trasnformatif. ${ }^{14}$ Pergeseran perspektif terjadi ketika keyakinan mendasar menghadapi tantangan, biasanya disertai perasaan kuat dan reaksi emosi seperti sedih, malu atau marah. ${ }^{4,14}$

Kedua, penugasan refleksi post test tidak menggunakan multimedia tetapi penugasan refleksi naratif dengan tulisan tangan, dapat kurang meningkatkan motivasi dan keterlibatan mahasiswa. Keterlibatan dan motivasi merupakan poin penting dalam meningkatkan refleksi. Sebuah penelitian pada mahasiswa tahun pertama menyoroti "generasi net" lebih memilih pendekatan dengan aktivitas kreatif dan kegiatan kelompok. Pengalaman menggunakan multimedia seperti digital storytelling, tidak hanya meningkatkan keterlibatan tetapi juga memotivasi pembelajaran mendalam. ${ }^{15}$

Ketiga, bisa disebabkan umpan balik tidak diberikan secara reguler. Umpan balik yang diberikan secara reguler dengan pertanyaan dapat memprovokasi pemikiran, dengan harapan meningkatkan refleksi. ${ }^{2}$ Peserta didik yang menerima umpan balik reguler jarang mengulang pengalaman lalu 
mengesankan pemberian umpan balik secara reguler meningkatkan refleksi kritis dalam bentuk transformasi learning. ${ }^{16}$ Akan tetapi seberapa frekuensi pemberian umpan balik mempengaruhi refleksi kritis, belum ditemukan literaturnya oleh peneliti.

Penyebab lain yang menjadi pertimbangan penting penulis adalah kurangnya trustworthy mahasiswa terhadap pemberi umpan balik karena instruktur bukan dosen partisipan. Penelitian yang melibatkan 600 perawat menunjukkan instruktur merupakan faktor penting yang mendukung refleksi kritis, lebih penting daripada pengalaman perawat sendiri maupun pelatihan selama di akademik. ${ }^{17}$ Ini menunjukkan pentingnya pendidik mengembangkan trustworthy dengan peserta didik jika ingin menghasilkan refleksi berkualitas tinggi pada sebuah jurnal. Penelitian MurdochEateon dan Sargeant menunjukkan peserta didik di tahun awal cenderung kurang menghargai umpan balik yang di berikan oleh orang lain selain senior akademik mereka. ${ }^{18}$ Hal ini memperlihatkan pengaruh identitas pemberi umpan balik berpotensi membentuk dampak umpan balik. Survey yang dilakukan pada residen kedokteran menyatakan bahwa kepercayaan dan penghargaan terhadap pendidik adalah faktor yang akan membuat mereka lebih mudah menerima umpan balik. ${ }^{19}$

Hasil penelitian juga menunjukkan penurunan kemampuan refleksi mahasiswa secara umum dimaknaidenganpentingnyamelakukanmaintenance terhadap kemampuan refleksi mahasiswa. Menulis jurnal secara reguler membantu mahasiswa mengembangkan kebiasaan dan ketrampilan refleksi. Jika mahasiswa tidak didorong untuk menulis jurnal secara reguler, dapat di mengerti jika kualitas refleksinya mengecewakan. ${ }^{20} \mathrm{Hal}$ ini bisa terlihat pada penelitian quasi eksperimental dari Fukude dan Bruce menunjukkan adanya perbedaan kemampuan refleksi mahasiswa keperawatan pada kelompok perlakuan yang menulis refleksi tiap minggu selama rotasi klinik dibandingkan dengan kelompok yang tidak melakukan refleksi. ${ }^{21}$ Kelompok perlakuan lebih baik dalam hal menggali alternatif dan formulasi respon di kemudian hari. Aronson memberi tip untuk mengintegrasikan pembelajaran refleksi secara longitudinal ke dalam kurikulum dan menempatkan pembelajaran ketrampilan reflektid dari tahap akademik ke tahap profesi. $^{22}$

Terdapat beberapa faktor yang menjadikan refleksi berkualitas tinggi atau menghambat refleksi, yaitu ${ }^{23}$ :

- Kejelasan harapan

Mahasiswa perlu memahami dengan jelas akan tujuan dan apa yang diharapkan dari tugas penulisan. Apakah sejalan dengan program pembelajaran, siapa yang akan membaca, apakah ada penilaian, apakah ada syarat khusus?

- Pelatihan

Pentingnya pelatihan yang adekuat untuk membantu penulisan yang lebih efektif. ${ }^{24}$

- Respon dan umpan balik

Respon yang baik dapat membuat peserta didik termotivasi dan terisnpirasi menulis refleksi/jurnal secara mendalam dan kritis. ${ }^{25}$ Kemampuan pendidik dalam memberikan umpan balik penting, oleh sebab itu perlu menilai kompetensi guru dalam mendorong pembelajaran reflektif. ${ }^{26}$

- Nilai sebagai motivator

Peserta didik akan lebih termotivasi oleh nilai. $23,24,27$ Oleh karena itu, pertimbangkan memilih memberi penghargaan kepada peserta didik yang membuat refleksi naratif mendalam dan kritis dengan nilai yang lebih tinggi.

- Menyediakan struktur

Struktur berupa saran kepada peserta didik (pertanyaan spesifik, tugas menulis, dan aktivitas) dinyatakan dapat menghindari penulisan yang tidak bermakna dan memungkinkan refleksi mendalam. ${ }^{23}$ Menyediakan struktur bagi pemula untuk menulis refleksi naratif/jurnal adalah penting.

Keterbatasan penelitian ini adalah penelitian hanya menggunakan metode kuantitatif dengan menggunakan uji statistik non parametrik (Wilcoxon dan Mann-Whitney) untuk menganalisa kemampuan refleksi kritis mahasiswa dengan pemberian umpan balik. ${ }^{9}$ Penelitian ini tentu akan lebih kaya jika menggali faktor lain 
seperti persepsi mahasiswa terhadap pemberian umpan balik, persepsi mahasiswa terhadap instruktur yang memberikan umpan balik, serta bagaimana motivasi mahasiswa dalam melakukan refleksi kritis. Meskipun secara lisan beberapa mahasiswa mengungkapkan perasaan senang dengan pemberian umpan balik yang membuat mereka mengetahui sejauh mana kemampuannya. Keterbatasan lain adalah menggunakan instruktur mahasiswa S2 yang bukan dosen mahasiswa kedokteran sehingga ada kemungkinan rendahnya trustworthy yang dari mahasiswa. Pemberian umpan balik yang tidak segera (di semester 4) terhadap hasil refleksi naratif mahasiswa (akhir semester 2) karena keterbatasan peneliti menunggu prosedur ethical clearence. Antisipasi yang dilakukan berupa saat pemberian umpan balik, mahasiswa diberi kesempatan membaca hasilnya untuk mengingat kembali refleksi naratif yang telah dilakukannya.

\section{KESIMPULAN}

Kemampuan refleksi mahasiswa pada pre dan post test berada pada tahap refleksi dan pemberian umpan balik satu kali tidak dapat meningkatkan kemampuan dari tahap refleksi ke tahap refleksi kritis. Terdapat penurunan secara umum pada kemampuan refleksi mahasiswa setelah 6 bulan.

\section{SARAN}

Pembelajaran refleksi perlu dimasukkan ke dalam kurikulum dengan meyediakan struktur pembelajaran refleksi secara longitudinal dari tahap akademik hingga tahap profesi dengan penugasan maupun aktivitas refleksi secara reguler. Desain pembelajaran refleksi perlu mempertimbangkan: suasana pembelajaran yang nyaman, penilaian formatif sebagai diagnosa dan terapi bagi mahasiswa, dan dosen yang terlatih.

\section{DAFTAR PUSTAKA}

1. Wald HS, Borkan, JM, Taylor JS, Anthony D, Reis SP. Fostering and evaluating reflective capacity in medical education: developing the REFLECT rubric for assessing reflective writing. Academic Medicine. 2012; 87(1):41-50.

2. Koole S, Dornan T, Aper L, Weber B, Scherpbier A, Valcke M, Cohen-Schotanus J, Derese A. Factor confounding the assessment of reflection: a critical review. BMC Medical Education. 2011;11:104.

3. Bolton G. Reflective practice: Writing and professional development. Sage publications. Los Angeles. 2010.

4. Kember D, editor. Reflective teaching and learning in the health professions: Action research in professional education. John Wiley \& Sons, New Jersey. 2008.

5. Mann K, Gordon J, MacLeod A. Reflection and reflective practice in health professions education: a systematic review. Advances in health sciences education. 2009; 14(4):595-621.

6. Konsil Kedokteran Indonesia. Standar Kompetensi Dokter Indonesia. Jakarta. 2012.

7. Shute VJ. Focus on Formative Feedback. Review of Educational Research. 2008; 78(1):153-89.

8. Chretien K, Goldman E, Faselis C. The reflective writing class blog: using technology to promote reflection and professional development. Journal of general internal medicine. 2008; 23(12):20662070.

9. Creswell JW. Research Design. Qualitative, Quantitative, and Mixed Methods Approaches, Fourth Edition. Sage Publication. Los Angeles. 2014.

10. Murti B. Validitas dan reliabilitas pengukuran dalam Matrikulasi Program studi Doktoral. Fakultas Kedokteran Universitas Negeri Solo. 2011.

11. Gagne RM, Briggs LJ, Wager WW.Principle of Instructional Design. Harcout Brace Jovanovich College Publisher. Orlando. 1992.

12. Field A. Discovering statistic using IBM SPSS statistic. Fourth Edition. Sage. Los Angeles. 2013.

13. Sugiyono, D. Metode Penelitian Kuantitatif dan Kualitatif dan R\&D. Penerbit Alfabeta. Bandung. 2011

14. Sandars J. The use of reflection in medical education: AMEE Guide No. 44. Medical teacher. 2009; 31(8):685-695.

15. Sandars J, Murray C, Pellow W. Twelve tips for using digital storytelling to promote reflective learning by medical students. Medical teacher. 2008;30(8):774749.

16. Quinton S, Smallbone T. A feeding forward: using feedback to promote student reflection and learning a teaching model. Innovation Education and teaching International. 2010;47(1):125-135.

17. Paget T. Reflective practice and clinical outcomes: Practitioners' view on how reflective practice has influenced their clinical practice. Journal of clinical nursing. 2001;10(2):204-214. 
18. Murdoch-Eaton D, Sargeant J. Maturational differences in undergraduate medical studens' perception about feedback. Medical education. 2012;46:711-721.

19. Ramani S, Krackov SK. Twelve tips for giving feedback effectively in the clinical environment. Medical teacher. 2012;34:787-791.

20. O'Connel TS, Dyment JE. REflection on using journals in higher education: A focus group discussion with faculty. Assessment and evaluation in higher education. 2006;31(6):671-691.

21. Fukude L, Bruce J. Journaling: a quasi eksperimental study of student nurses' reflective learning ability. 2003. Curationis diunduh dari http://curationis.org. za/index.php/curationis/article/viewFile/783/720 pada tanggal 2 juni 2017 di Yogyakarta.

22. Aronson L. Twelve tips for teaching reflection at all levels of medical education. Medical teacher. 2011;33(3):200-205.

23. O'Connel TS, Dyment JE. The quality of reflection in student journals: a review of limiting and enabling factors. Innovation High Education. 2010;35:233244.
24. O'Connel TS, Dyment JE. Journal writing is something we have to learn on our own. The result of focus group discussion with recreation students. A journal of leasure studies and recreation education. 2003.;18(1):23-8.

25. Fisher K. Demiystifying critical reflection: Defining criteria for assessment. Higher education research and development. 2003;22(3):313-25.

26. Schaub-de Jong MA, Schonrock-Adema J, Dekker H, Venkerk M, Cohen-Schotanus J. Development of student rating scale to evaluate teacher competencies for facilitating reflective learning. Medical education. 2011;45(2):155-165.

27. Grant A, Kinnersley P, Metcalf E, Pill R, Houston H. Students' views of reflective learning techniques: an efficacy study at a medical school. Medical Education. 2006;40(4):379-388. 


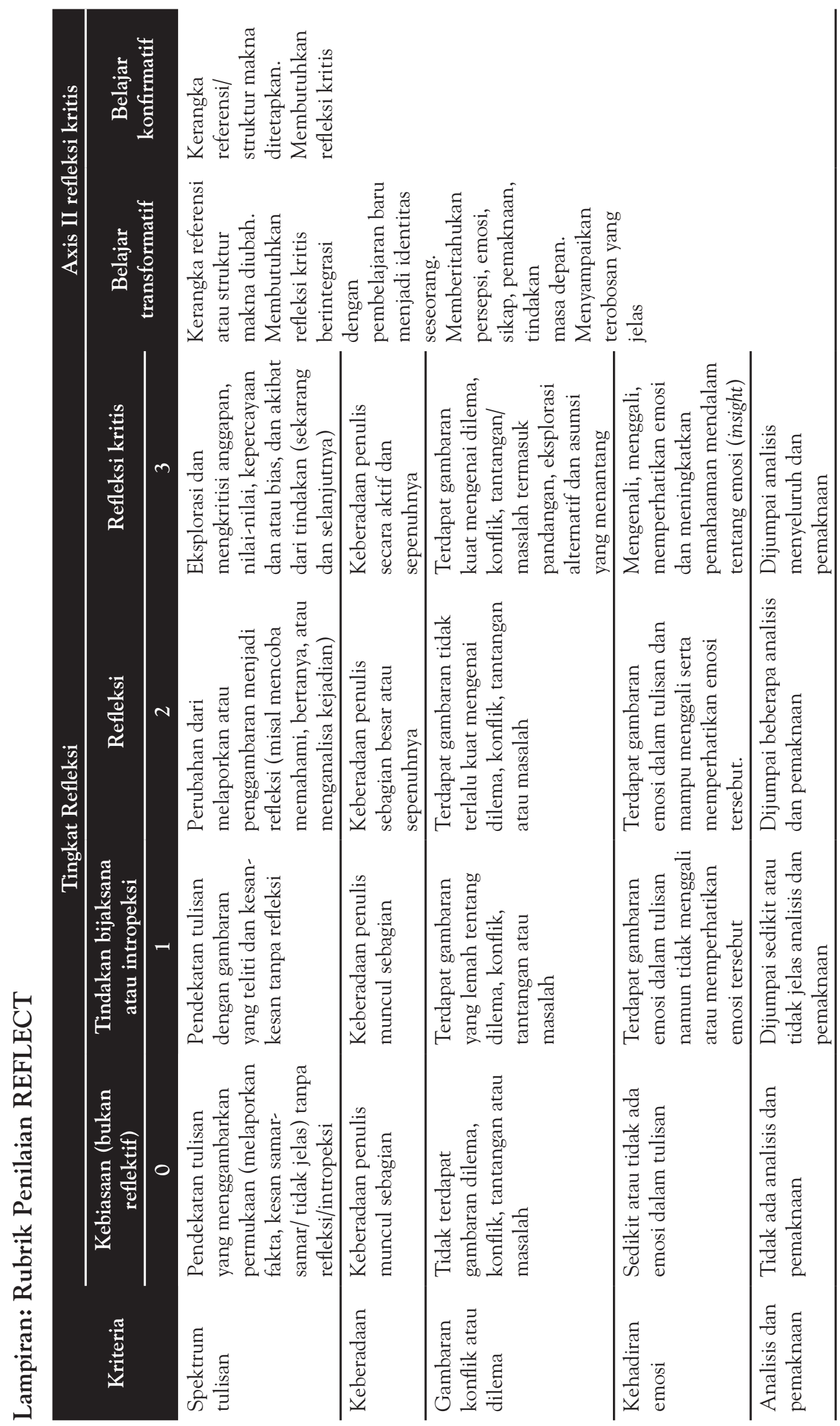

